\title{
Analisis Rasio Keuangan Untuk Menilai Kinerja Keuangan Sebelum Dan Sesudah Merger Pada PT. \\ Kalbe Farma.tbk"
}

\author{
M.Astri Yulidar \\ Universitas Widya Gama Mahakam Samarinda \\ threejuli@gmail.com
}

\begin{abstract}
Abstrak
Kinerja keuangan PT. Kalbe Farma ditinjau dari rasio profitabilitas terjadi fluktuasi, artinya rasio ini mengalami naik turun setiap tahunnya. Namun dilihat dari Net Profit Margin sebelum merger pada tahun 2002 sebesar 10,42\%, tahun 2003 sebesar 11,18\%, tahun 2004 sebesar 10,91\% dan sesudah merger pada tahun 2005 sebesar 10.66\%, tahun 2006 sebesar 11,14\%, tahun 2007 sebesar 10,07\%, tahun 2008 sebesar $8,97 \%$, tahun 2009 sebesar 10,22\%, tahun 2010 sebesar 12,58\%, pada tahun 2011 sebesar 14,11\%, pada tahun 2012 sebesar 12,99\%, tahun 2013 sebesar 12,52\%. Dilihat dari Return On Investmentsebelum merger pada tahun 2002 sebesar 13,24\%, tahun 2003 sebesar 13,19\%, tahun 2004 sebesar 12,34\% dan sesudah merger pada tahun 2005 sebesar 13,51\%, tahun 2006 sebesar 14,63\%, tahun 2007 sebesar $13,73 \%$, tahun 2008 sebesar 12,39\%, tahun 2009 sebesar $14,33 \%$, tahun 2010 sebesar 18,29\%, pada tahun 2011 sebesar 18,61\%, pada tahun 2012 sebesar 18,82\%, tahun 2013 sebesar 17,71\%. Dan dilihat dari Return On Equitysebelum merger pada tahun 2002 sebesar 54,49\%, tahun 2003 sebesar 38,95\%, tahun 2004 sebesar 30,54\%dan sesudah merger pada tahun 2005 sebesar 26,84\%, tahun 2006 sebesar 22,59\%, tahun 2007 sebesar 20,84\%, tahun 2008 sebesar 19,51\%, tahun 2009 sebesar 21,55\%, tahun 2010 sebesar 23,94\%, pada tahun 2011 sebesar 23,63\%, pada tahun 2012 sebesar 24,04\%, tahun 2013 sebesar 23,58\%.
\end{abstract}

Keywords : ROA, ROI

pendahuluan

\subsection{Latar Belakang}

Adanya globalisasi dan persaingan bebas menuntut setiap perusahaan untuk selalu mengembangkan strateginya agar dapat bertahan hidup, berkembang dan berdaya saing. Strategi bersaing merupakan usaha untuk mengembangkan (membesarkan) perusah ${ }^{1}$ aan sesuai dengan ukuran besaran yang disepakati untuk mencapai tujuan jangka panjang perusahaan atau disebut juga strategi pertumbuhan. Strategi ini dapat dilaksanakan melalui memperluas kegiatan perusahaan yang sudah ada, misalnya dengan cara menambahkan kapasitas produk, membangun perusahaan baru ataupun dengan cara bergabung diperusahaan lain.

Apabila perusahaan memperluas usahanya dengan cara menambah kapasitas produksi atau mendirikan perusahaan baru, maka cara ini disebut dengan ekspansi. Sedangkan cara lain yakni dengan menggabungkan perusahaan lain disebut dengan merger.

Merger merupakan perbuatan hukum yang dilakukan oleh satu perseroan atau lebih untuk menggabungkan diri dengan perseroan lain yang sudah ada yang mengakibatkan aktiva dan pasiva dari perseroan yang menggabungkan diri beralih demi hukum perseroan yang menerima penggabungan.

PT. Kalbe Farma Tbk adalah perusahaan yang bergerak dalam bidang industri farmasi dan produk-produk yang berkaitan dengan kesehatan. Semakin banyaknya perusahaan farmasi, menimbulkan iklim persaingan yang lebih ketat. Saat ini jumlah perusahaan farmasi di Indonesia berjumlah lebih dari 200 perusahaan. Hal ini membuat perusahaan farmasi saling berlomba - lomba untuk tetap mempertahankan posisinya. Begitu pula yang dilakukan oleh PT. Kalbe Farma Tbk, PT. Dankos 
Laboratories Tbk dan PT. Enseval Tbk. Untuk mengurangi persaingan sekaligus menciptakan efisiensi, kedua perusahaan tersebut akhirnya melakukan peleburan usaha atau merger. Berikut adalah hasil analisis dari kinerja keuangan sebelum merger dari masing - masing perusahaan yang diukur menggunakan analisis rasio keuangan :

Tabel 1.1 Analisis Kinerja Keuangan Sebelum Merger.

\begin{tabular}{|c|c|c|c|}
\hline RASIO & PT. Kalbe & PT. Dankos & PT. Enseval \\
\hline \multicolumn{4}{|l|}{ 1. Rasio Profitabilitas : } \\
\hline a. Net Profit Margin & $10,91 \%$ & $16,03 \%$ & $3,95 \%$ \\
\hline b. Return On Investment & $12,34 \%$ & $15,73 \%$ & $10,77 \%$ \\
\hline c. Return On Equity & $30,54 \%$ & $29,77 \%$ & $30,89 \%$ \\
\hline \multicolumn{4}{|l|}{ 2. Rasio Pasar: } \\
\hline a. Earning Per Share (EPS) & $4584,50 \%$ & $8999,47 \%$ & $7808,02 \%$ \\
\hline b. Price Earning Ratio & $10,81 \%$ & $12,33 \%$ & $12,81 \%$ \\
\hline \multicolumn{4}{|l|}{ 3. Rasio Aktivitas } \\
\hline a. Total Assets Turn Over (TATO) & 1,19 kali & 9,81 kali & 27,22 kali $i$ \\
\hline \multicolumn{4}{|l|}{ 4. Rasio Likuid itas } \\
\hline a. Current Ratio & $300,98 \%$ * & $295,27 \%$ & $171,38 \%$ \\
\hline \multicolumn{4}{|l|}{ 5. Rasio Solvabilitas } \\
\hline a. Total Debt to Total Assets Ratio & $50,96 \%$ & $46,52 \%$ क & $64,93 \%$ \\
\hline
\end{tabular}

Keterangan : $=$ Lebih Baik

Sumber : Hasil Penelitian

Bertitik tolak dari merger yang dilakukan PT Kalbe Farma Tbk pada tahun 2005 tersebut maka peneliti tertarik untuk menganalisis pengaruh merger yang dilakukan oleh menajemen terhadap rasio keuangan perusahaan. Untuk itu penulis tertarik memilih judul "Analisis Rasio Keuangan Untuk Menilai Kinerja Keuangan Sebelum Dan Sesudah Merger Pada PT. Kalbe Farma.tbk”

\section{Rumusan Masalah}

Berdasarkan judul yang dikemukakan serta latar belakang di atas, maka yang menjadi pokok permasalahan dalam penelitian ini adalah :

"Apakah dengan melakukan mergerkinerja keuangan PT. Kalbe Farma berdasarkan Rasio Profitabilitas, Rasio Aktivitas, Rasio Likuiditas, Rasio Pasar dan Rasio Solvabilitas mengalami peningkatan.”

\section{Model Konseptual}

Berdasarkan masalah penelitian dan dasar teori maka dapat disusun model konseptual sebagai berikut : 


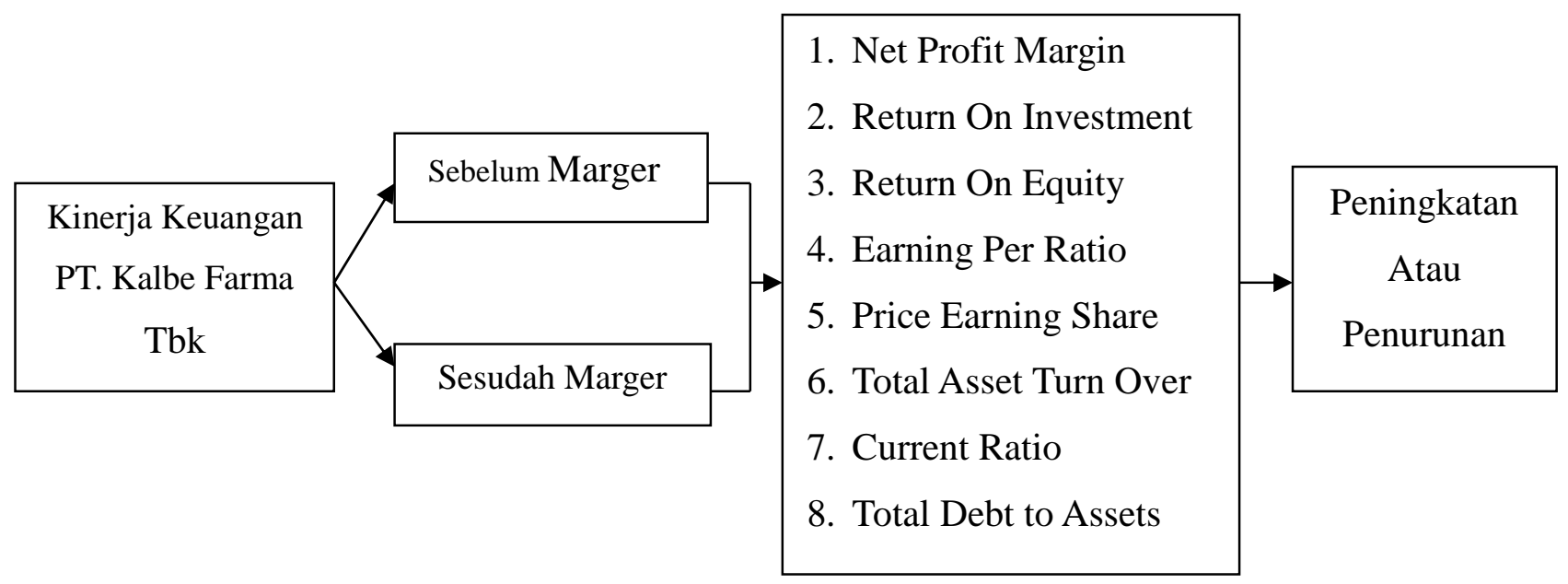

METODOLOGI PENELITIAN

\section{Definisi Operasional Variabel}

Agar tidak terjadi kesalahan penafsiran mengenai pengertian - pengertian variabel yang digunakan dalam penelitian ini, maka mengenai defenisi operasional yang akan dijabarkan sebagai berikut :

Laporan keuangan adalah hasil akhir dari suatu proses pencatatan yang merupakan

a. suatu ringkasan transaksi - transaksi keuangan yang terjadi pada PT. Kalbe Farma dari tahun 2002 - 2004 sebelum marger dan 2005 - 2013 sesudah marger.

b. Neraca adalah laporan yang menunjukan keadaan keuangan dari tahun 2002 - 2004 sebelum marger dan 2005 -2013 sesudah marger pada PT. Kalbe Farma.

c. Laporan laba rugi adalah laporan yang menunjukan hasil usaha dan biaya - biaya dari tahun 2002 - 2004 sebelum marger dan 2005 - 2013 sesudah marger pada PT. Kalbe Farma.

d. Kinerja Keuangan adalah sebuah prestasi keuangan yang dapat dicapai PT. Kalbe Farma dari tahun 2002 - 2004 sebelum marger dan 2005 - 2013 sesudah marger pada PT. Kalbe Farma.

e. Analisis rasio keuangan adalah perhitungan rasio - rasio untuk menilai keadaan keuangan PT. Kalbe Farma dari tahun 2002 - 2004 sebelum marger dan 2005 - 2013 sesudah marger, adapun rasio - rasio yang digunakan adalah Rasio Profitabilitas, Rasio Aktivitas, Rasio Likuiditas, Rasio Pasar dan Rasio Solvabilitas.

\section{f. Populasi Dan Sampel}

Populasi dan sampel adalah keseluruhan dari objek penelitian yang akan diteliti. Dalam penelitian ini, objek penelitiannya adalah PT Kalbe Farma Tbk. yang merupakan perusahaan hasil merger dengan PT. Dankos Laboratories Tbk dan PT. Enseval Tbk adapun sampel yang digunakan adalah laporan laba - rugi dan neraca dari tahun 2002, 2003, 2004 sebelum marger dan 2005, 2006, 2007, 2008, 2009, 2010, 2011, 2012, 2013 sesudah marger pada PT. Kalbe Farma.

\section{Teknik Pengumpulan Data}

Guna memperoleh data yang diperlukan dalam penelitian ini maka peneliti menggunakan teknik pengumpulan data sebagai berikut:

a. Data Sekunder

Yaitu data yang diperoleh dari pihak lain berupa laporan publikasi. Data yang digunakan dalam penelitian ini berupa annual report PT. Kalbe Farma Tbk periode 2002 - 2013. Data yang digunakan dalam penelitian ini diperoleh dari www.kalbe.co.id dan www.idx.co.id 


\section{b. Dokumentasi}

Pengumpulan data dengan cara mencatat atau mendokumentasikan data yang sudah ada. Data yang digunakan dalam penelitian ini berupa laporan keuangan auditan PT. Kalbe Farma Tbk periode 2002 - 2013.

c. Penelitian Kepustakaan

Penelitian yang dilaksanakan dengan membaca dan mengutip buku literature, tulisan tulisan serta laporan - laporan yang ada hubungan dengan penelitian ini.

\section{Gambaran Obyek Yang Di Teliti}

Langkah pertama yang dilakukan penulis dalam melaksanakan studi kasus ini adalah dengan cara mencari kelemahan dan kelebihan dari masing- masing perusahaan, sehingga dapat menjelaskan mengapa PT. Dankos Laboratories Tbk dan PT. Enseval Tbk layak menjadi perusahaan yang akan dimerger. Metode yang digunakan adalah dengan cara analisis rasio, karena analisis rasio dapat menggambarkan kondisi keuangan dan hasil operasi suatu perusahaan. Diasumsikan dengan menggunakan laporan keuangan PT. Dankos Laboratories dan PT. Enseval Tbk pada tahun 2004. Maka analisis rasio masing masing perusahaan sebelum merger adalah sebagai berikut :

1. Analisis Rasio PT. Dankos Laboratories Tbk.

a. Rasio Profitabilitas

$$
\begin{aligned}
& \text { Net Profit Margin }=\frac{\text { Laba setelah Bunga dan Pajak }}{\text { Penjualan Bersih }} \times 100 \% \\
& \text { Tahun } 2004=\frac{160.735 .057 .721}{1.002 .095 .806 .299} \times 100 \% \\
& =16,03 \%
\end{aligned}
$$

Perusahaan memperoleh $16,03 \%$ dari seluruh penjualan yang telah dilakukan yang berarti bahwa untuk setiap Rp.1,00 penjualan bersih dapat menghasilkan laba sebesar Rp. 0,1603. Laba ini merupakan laba bersih setelah dikurangi seluruh pengeluaran termasuk pajak.

$$
\begin{gathered}
\text { Return On Invesment }=\frac{\text { Laba setelah Bunga dan Pajak }}{\text { Total Aktiva }} \times 100 \% \\
\text { Tahun } 2004=\frac{160.735 .057 .721}{1.021 .727 .560 .322} \times 100 \% \\
=15,73 \%
\end{gathered}
$$

Perusahaan mampu menghasilkan laba dari investasi yang ditanamkan serta mengelola perputaran aktiva terhadap investasi sebesar $15,73 \%$ yang berarti setiap kemampuan modal yang diinvestasikan dalam Rp. 1,00 mampu menghasilkan laba sebesar Rp. 0,1573.

$$
\begin{gathered}
\text { Return On Equity }=\frac{\text { Laba Setelah Bungan dan Pajak }}{\text { Modal Sendiri }} \times 100 \% \\
\text { Tahun } 2004=\frac{160.735 .057 .721}{539.884 .588 .210} \times 100 \% \\
=29,77 \%
\end{gathered}
$$

Perusahaan memiliki kemampuan dalam memanfaatkan modal yang dimiliki untuk memperoleh laba, yaitu sebesar 29,77\% yang berarti bahwa setiap Rp,1,00 modal sendiri dapat menghasilkan laba sebesar Rp. 0,2977

$$
\begin{gathered}
\text { Earning Per Share }=\frac{\text { Pendapatan Bersih }}{\text { Iumlah Sahamyg Beredar }} \times 100 \% \\
\text { Tahun } 2004=\frac{160.735 .057 .721}{1.786 .050 .000} \times 100 \% \\
=8999,47 \%
\end{gathered}
$$


Perusahaan memiliki Tingkat laba bersih yang siap dibagikan bagi semua pemegang saham perusahaan sebesar 8999,47\%yang berarti setiap Rp. 1,00 per lembar saham dapat menghasilkan laba untuk pemegang saham sebesar Rp. 89,9947. Semakin tinggi rasio ini maka semakin baik karena banyak investor yang mau membeli saham tersebut sehingga menyebabkan harga saham akan tinggi.

$$
\begin{aligned}
\text { Price Earning Ratio } & =\frac{\text { Harga Pasar Saham }}{\text { Laba Bersih Per Saham (EPS) }} \times 100 \% \\
\text { Tahun } 2004 & =\frac{1.110}{8999,47} \times 100 \% \\
= & 12,33 \%
\end{aligned}
$$

Perusahaan memiliki laba terhadap harga saham sebesar 12,33\%, yang berarti investor bersedia membayar Rp. 0,1233 untuk setiap Rp. 1,00 dari laba bersih yang dihasilkan perusahaan. Semakin besar nilai Price Earning Ratio sebuah saham maka semakin mahal saham tersebut.

$$
\begin{aligned}
& \text { Total Assets Turn Over }=\frac{\text { Penjualan }}{\text { Total Aktiva }} \times 1 \text { Kali } \\
& \text { Tahun } 2004=\frac{1.002 .095 .806 .299}{1.021 .727 .560 .322} \times 1 \text { Kali } \\
& =9,81 \mathrm{kali}
\end{aligned}
$$

Aktiva yang dimiliki perusahaan lebih cepat berputar dan meraih laba serta menunjukan semakin efesien penggunaan keseluruhan aktiva dalam menghasilkan penjualan yaitu sebesar 9,81 kali , yang artinya penjualan yang dihasilkan sebesar 9,81 kali dari total aktiva. Semakin tinggi rasio ini maka semakin baik karena semakin efisien perusahaan dalam meraih laba.

$$
\begin{aligned}
& \text { Current Ratio }=\frac{\text { Aktiva Lancar }}{\text { Hutang Lancar }} \times 100 \% \\
& \text { Tahun } 2004=\frac{794.984 .975 .101}{269.235 .140 .658} \times 100 \% \\
& =295,27 \%
\end{aligned}
$$

Perusahaan mampu membiayai hutang jangka pendeknya sebesar 295,27\% yang berarti setiap Rp. 1,00 hutang lancar dijaminkan Rp. 2,9527 oleh aktiva lancar. Semakin tinggi rasio ini maka semakin baik, karna semakin efesien perusahaan dalam memenuhi hutang jangka pendeknya.

$$
\begin{aligned}
& \text { Total Debt to Total Assets }=\frac{\text { Total Hutang }}{\text { Total Aktiva }} \times 100 \% \\
& \text { Tahun } 2004=\frac{475.382 .203 .947}{1.021 \cdot 727 \cdot 560.322} \times 100 \% \\
& =46,52 \%
\end{aligned}
$$

Perusahaan memilik total aktiva yang dibiayai dengan menggunakan dana yang berasal dari hutang yaitu sebesar $46,53 \%$ yang berarti bahwa setiap Rp. 1,00 total hutang dijaminkan oleh total aktiva sebesar Rp. 4,652.

2. Analisis Rasio PT. Enseval Tbk.

b. Rasio Profitabilitas

$$
\begin{gathered}
\text { Net Profit Margin }=\frac{\text { Laba setelah Bunga dan Pajak }}{\text { Penjualan Bersih }} \times 100 \% \\
\text { Tahun } 2004=\frac{178.022 .946 .074}{4.496 .559 .166 .871} \times 100 \% \\
=3,95 \%
\end{gathered}
$$

Perusahaan memperoleh $3,95 \%$ dari seluruh penjualan yang telah dilakukan yang berarti bahwa untuk setiap Rp.1,00 penjualan bersih dapat menghasilkan laba sebesar Rp. 0,0395. Laba ini merupakan laba bersih setelah dikurangi seluruh pengeluaran termasuk pajak.

$$
\text { Return On Invesment }=\frac{\text { Laba setelah Bunga dan Pajak }}{\text { Total Aktiva }} \times 100 \%
$$




$$
\begin{gathered}
\text { Tahun } 2004=\frac{178.022 .946 .074}{1.651 .987 .843 .298} \times 100 \% \\
=10,77 \%
\end{gathered}
$$

Peusahaan mampu menghasilkan laba dari investasi yang ditanamkan serta mengelola perputaran aktiva terhadap investasi sebesar $10,77 \%$ yang berarti setiap kemampuan modal yang diinvestasikan dalam Rp. 1,00 mampu menghasilkan laba sebesar Rp. 0,1077.

$$
\begin{gathered}
\text { Return On Equity }=\frac{\text { Laba Setelah Bungan dan Pajak }}{\text { Modal Sendiri }} \times 100 \% \\
\text { Tahun } 2004=\frac{178.022 .946 .074}{576.163 .819 .825} \times 100 \% \\
=30,89 \%
\end{gathered}
$$

Perusahaan memiliki kemampuan dalam memanfaatkan modal yang dimiliki untuk memperoleh laba, yaitu sebesar 30,89 \% yang berarti bahwa setiap Rp.1,00 modal sendiri dapat menghasilkan laba sebesar Rp. 0,3089.

$$
\begin{gathered}
\text { Earning Per Share }=\frac{\text { Pendapatan Bersih }}{\text { Jumlah Saham yg Beredar }} \times 100 \% \\
\text { Tahun } 2004=\frac{178.022 .946 .074}{2.280 .000 .000} \times 100 \% \\
=7808,02 \%
\end{gathered}
$$

Perusahaan memiliki Tingkat laba bersih yang siap dibagikan bagi semua pemegang saham perusahaan sebesar 7808,02\%yang berarti setiap Rp. 1,00 per lembar saham dapat menghasilkan laba untuk pemegang saham sebesar Rp. 78,0802. Semakin tinggi rasio ini maka semakin baik karena banyak investor yang mau membeli saham tersebut sehingga menyebabkan harga saham akan tinggi.

$$
\begin{gathered}
\text { Price Earning Ratio }=\frac{\text { Harga Pasar Saham }}{\text { Laba Bersih Per Saham (EPS) }} \times 100 \% \\
\text { Tahun } 2004=\frac{\text { Rp. } 1.000}{7.808,02} \times 100 \% \\
=12,81 \%
\end{gathered}
$$

Perusahaan memiliki laba terhadap harga saham sebesar $12,81 \%$, yang berarti berarti investor bersedia membayar Rp. 0,1281 untuk setiap Rp. 1,00 dari laba bersih yang dihasilkan perusahaan. Semakin besar nilai Price Earning Ratio sebuah saham maka semakin mahal pula saham tersebut.

$$
\begin{aligned}
& \text { Total Assets Turn Over }=\frac{\text { Penjualan }}{\text { Total Aktiva }} \times 1 \text { Kali } \\
& \begin{aligned}
\text { Total Assets Turn Over } & =\frac{449.655 .916 .871}{1.651 .987 .843 .298} \times 1 \text { Kali } \\
& =27,22 \mathrm{kali}
\end{aligned}
\end{aligned}
$$

Aktiva yang dimiliki perusahaan lebih cepat berputar dan meraih laba serta menunjukan semakin efesien penggunaan keseluruhan aktiva dalam menghasilkan penjualan yaitu sebesar 27,22 kali, yang artinya penjualan yang dihasilkan sebesar 1,27 kali dari total aktiva. Semakin tinggi rasio ini maka semakin baik karena semakin efisien perusahaan dalam meraih laba.

$$
\begin{aligned}
& \text { Current Ratio }=\frac{\text { Aktiva Lancar }}{\text { Hutang Lancar }} \times 100 \% \\
& \text { Tahun } 2004=\frac{1.477 .873 .270 .785}{862.289 .669 .477} \times 100 \% \\
& =171,38 \%
\end{aligned}
$$

Perusahaan mampu membiayai hutang jangka pendeknya sebesar $171,38 \%$ yang berarti setiap Rp. 1,00 hutang lancar dijaminkan Rp. 1,7138 oleh aktiva lancar. Semakin tinggi rasio ini maka semakin baik, karna semakin efesien perusahaan dalam memenuhi hutang jangka pendeknya. 


$$
\begin{gathered}
\text { Total Debt to Total Assets }=\frac{\text { Total Hutang }}{\text { Total Aktiva }} \times 100 \% \\
\text { Tahun } 2004=\frac{1.072 .686 .025 .761}{1.651 .987 .843 .298} \times 100 \% \\
=64,93 \%
\end{gathered}
$$

Perusahaan memilik total aktiva yang dibiayai dengan menggunakan dana yang berasal dari hutang yaitu sebesar 64,93\%yang berarti bahwa setiap Rp. 1,00 total hutang dijaminkan oleh total aktiva sebesar Rp. 6,493.

\section{Pembahasan}

Berdasarkan perhitungan terhadap laporan keuangan pada PT. Kalbe Farma,tbk yang meliputi Rasio Profitabilitas, Rasio Aktivitas, Rasio Likuiditas, Rasio Pasar dan Rasio Solvabilitas tersebut di atas, maka dapat penulis rincikan dalam tabel seperti di bawah ini :

\begin{tabular}{|c|c|c|c|}
\hline Keterangan & 2002 & 2003 & 2004 \\
\hline \multicolumn{4}{|l|}{ Rasio Profitabilitas : } \\
\hline Net Profit Margin & $10,42 \%$ & $11,18 \%$ & $8,94 \%$ \\
\hline Return On Investment & $13,24 \%$ & $13,19 \%$ & $10,65 \%$ \\
\hline Return On Equity & $54,49 \%$ & $38,95 \%$ & $28,19 \%$ \\
\hline \multicolumn{4}{|l|}{ Rasio Pasar: } \\
\hline Earning Per Share (EPS) & $6573,42 \%$ & $3975,63 \%$ & $5549,37 \%$ \\
\hline Price Earnings Ratio & $4,56 \%$ & $25,15 \%$ & $10,81 \%$ \\
\hline \multicolumn{4}{|l|}{ Rasio Aktivitas : } \\
\hline Total Assets Turn Over & 1,27 kali & 1,18 kali & 1,19 kali \\
\hline \multicolumn{4}{|l|}{ Rasio Likuiditas : } \\
\hline Current Ratio & $117,66 \%$ & $156,80 \%$ & $300,98 \%$ \\
\hline \multicolumn{4}{|l|}{ Rasio Solvabilitas : } \\
\hline Debt to Total Assets Ratio & $67,68 \%$ & $58,19 \%$ & $50,96 \%$ \\
\hline
\end{tabular}

Tabel 1.2 Ringkasan Penelitian Analisis Keuangan PT. Kalbe Farma.tbk

Sebelum Merger : 
Sesudah Merger :

\begin{tabular}{|c|c|c|c|c|c|c|c|c|c|}
\hline Keterangan & 2005 & 2006 & 2007 & 2008 & 2009 & 2010 & 2011 & 2012 & 2013 \\
\hline \multicolumn{10}{|l|}{ Rasio Profitabilitas : } \\
\hline Net Profit Margin & $10.66 \%$ & $11,14 \%$ & $10,07 \%$ & $8,97 \%$ & $10,22 \%$ & $12,58 \%$ & $14,11 \%$ & $12,99 \%$ & $12,52 \%$ \\
\hline Return On Investment & $13,51 \%$ & $14,63 \%$ & $13,73 \%$ & $12,39 \%$ & $14,33 \%$ & $18,29 \%$ & $18,61 \%$ & $18,82 \%$ & $17,71 \%$ \\
\hline Return On Equity & $26,84 \%$ & $22,59 \%$ & $20,84 \%$ & $19,51 \%$ & $21,55 \%$ & $23,94 \%$ & $23,63 \%$ & $24,04 \%$ & $23,58 \%$ \\
\hline \multicolumn{10}{|l|}{ Rasio Pasar : } \\
\hline Earning Per Share (EPS) & $6164,99 \%$ & $6661,88 \%$ & $7067,36 \%$ & $7378,70 \%$ & $9910,93 \%$ & $13720,82 \%$ & $16423,65 \%$ & $3489,63 \%$ & $4275,71 \%$ \\
\hline Price Earning Ratio & $19,46 \%$ & $26,27 \%$ & $16,98 \%$ & $5,42 \%$ & $13,11 \%$ & $23,69 \%$ & $20,70 \%$ & $30,09 \%$ & $28,07 \%$ \\
\hline \multicolumn{10}{|l|}{ Rasio Aktivitas : } \\
\hline Total Assets Turn Over & 1,24 kali & $1,31 \mathrm{kali}$ & 1,36 kali & 1,38 kali & 1,40 kali & 1,45 kali & 1,32 kali & 1,45 kali & 1,41 kali \\
\hline \multicolumn{10}{|l|}{ Rasio Likuiditas : } \\
\hline Current Ratio & $331,59 \%$ & $254,83 \%$ & $498,26 \%$ & $333,35 \%$ & $298,69 \%$ & $439,36 \%$ & $367,59 \%$ & $340,54 \%$ & $283,93 \%$ \\
\hline \multicolumn{10}{|l|}{ Rasio Solvabilitas : } \\
\hline Debt to Total Assets Ratio & $39,31 \%$ & $23,36 \%$ & $21,82 \%$ & $23,83 \%$ & $26,09 \%$ & $17,92 \%$ & $21,25 \%$ & $21,73 \%$ & $33,12 \%$ \\
\hline
\end{tabular}


Dari perhitungan di atas dapat dilihat :

- Dari Rasio Profitabilitas sebelum Merger :

\section{Net Profit Margin}

Berdasarkan analisis Net Profit Margin pada PT. Kalbe Farma untuk tahun 2002 sebesar 10,42\% yang artinya bahwa setiap Rp. 100, penjualan akan menghasilkan laba bersih Rp. 0,1042. Pada tahun 2003 terjadi peningkatan yaitu sebesar $11,18 \%$, yang artinya bahwa setiap Rp. 100, penjualan akan menghasilkan laba bersih sebesar Rp. 0,1118. Pada tahun 2004 terjadi penurunan yaitu sebesar 8,94\%, yang artinya berarti bahwa setiap Rp.100, penjualan akan menghasilkan laba bersih sebesar Rp. 0,894.

\section{Return On Investment}

Berdasarkan analisis Return On Investment pada PT. Kalbe Farma untuk tahun 2002 sebesar 13,24\% yang artinya bahwa dalam setiap penjualan Rp. 1,00 total aktiva yang digunakan memberikan keuntungan Rp. 0,1324. Pada tahun 2003 terjadi penurunan yaitu sebesar 13,19\%, yang artinya bahwa dalam setiap penjualan Rp. 1,00 total aktiva yang digunakan memberikan keuntungan Rp. 0,1319. Pada tahun 2004 juga terjadi penurunan yaitu sebesar 10,65\%, yang artinya bahwa dalam setiap penjualan Rp. 1,00 total aktiva yang digunakan memberikan keuntungan Rp. 0,1065.

Kondisi turunnya nilai Return On Investment pada tahun 2002 sampai 2004 tersebut menunjukkan bahwa penggunaan aktiva perusahaan belum efisien dan rendahnya tingkat laba yang dihasilkan oleh keseluruhan penggunaan aktiva. Return On Investment dapat ditingkatkan dengan cara menekan biaya operasional atau harga pokok penjualan sehingga laba yang diperoleh lebih tinggi.

\section{Return On Equity}

Berdasarkan analisis Return On Equity pada PT. Kalbe Farma untuk tahun 2002 sebesar 54,49\% yang artinya bahwa setiap Rp. 100 modal sendiri yang diinvestasikan akan menghasilkan laba bersih Rp. 0,5449. Pada tahun 2003 terjadi penurunan yaitu sebesar 38,95\%, yang artinya bahwa setiap Rp. 100, modal sendiri yang diinvestasikan menghasilkan laba bersih sebesar Rp. 0,3895. Pada tahun 2004 juga terjadi penurunan yaitu sebesar 28,19\%, yang artinya berarti bahwa setiap Rp.100 modal sendiri yang diinvestasikan menghasilkan laba bersih sebesar Rp. 0,2819

Dari hasil perhitungan Return On Equity dapat diketahui bahwa nilai Return On Equity menurun dari tahun 2002, 2003, dan 2004. Penurunan ini disebabkan karena tingginya biaya-biaya operasional, membuat laba yang dicapai tidak sebanding dengan modal yang dikeluarkan, sehingga kemampuan modal sendiri untuk menghasilkan laba bersih menurun dari tahun ke tahun.

\section{- Dari Rasio Pasar sebelum Merger}

\section{Earning Per Share}

Rasio ini menggambarkan besarnya pengembalian modal untuk setiap satu lembar saham yang dimiliki. Dari hasil perhitungan Earning Per Share pada tahun 2002 sebesar 6573,42\% yang berarti untuk setiap satu lembar saham yang dimiliki akan menghasilkan laba sebesar 0,657342. Pada tahun 2003 terjadi penurunan sebesar $3975,63 \%$ yang berarti untuk setiap satu lembar saham yang dimiliki akan menghasilkan laba sebesar 0,397563 dan pada tahun 2004 terjadi peningkatan sebesar 5549,37\% yang berarti untuk setiap satu lembar saham yang dimiliki akan menghasilkan laba sebesar 0,554937. Semakin tinggi rasio ini maka semakin baik karena laba yang dihasilkan juga semakin tinggi.

\section{Price Earning Ratio}

Price Earning Ratiomenunjukkan berapa banyak yang harus dibayarkan oleh investor untuksetiap rupiah pendapatan perusahaan. Semakin tinggi PER maka semakin besarkepercayaan investor terhadap masa depan perusahaan. Dari hasil perhitungan Price Earning Ratio pada tahun 2002 sebesar 4,56\%, yang berarti investor bersedia membayar Rp. 0,0456untuk setiap Rp. 1,00 dari laba bersih yang dihasilkan perusahaan. Pada tahun 2003 terjadi peningkatan sebesar 25,15\%, yang berarti investor bersedia membayar Rp. 0,02515 untuk setiap Rp. 1,00 dari laba bersih yang dihasilkan perusahaan. Dan pada tahun 2004 terjadi penurunan sebesar 10,81\%, yang berarti investor bersedia membayar Rp. 0,1081 untuk setiap Rp. 1,00 dari laba bersih yang dihasilkan perusahaan.

Semakin besar nilai Price Earning Ratio sebuah saham maka semakin mahal pula saham tersebut. 


\section{- Dari Rasio Aktivitas sebelum Merger}

\section{Total Asset Turn Over}

Berdasarkan analisis Total Asset Turn Over pada tahun 2002 sebesar 1,27 kali, yang artinya penjualan yang dihasilkan sebesar 1,27 kali dari total aktiva. Pada tahun 2003 Total Asset Turn Over mengalami penurunan sebesar 1,18 kali yang artinya penjualan yang dihasilkan sebesar 1,18 kali dari total aktiva. Dan pada tahun 2004 mengalami peningkatan yaitu sebesar 1,19 kali yang artinya penjualan yang dihasilkan sebesar 1,19 kali dari total aktiva.Nilai Total Asset Turn Over setiap tahun mengalami fluktuasi. Penurunan nilai Total Asset Turn Overdari tahun ke tahun ini menunjukkan bahwa kurangnya efisiensi penggunaan seluruh modal yang dimiliki dalam menghasilkan penjualan. Penurunan Total Asset Turn Overdari tahun ke tahun disebabkan karena adanya presentase kenaikan penjualan atau pendapatan jasa yang lebih kecil dibandingkan dengan presentase kenaikan aktiva.

\section{- Dari Rasio Likuiditas sebelum Merger \\ 7. Current Ratio}

Berdasarkan analisis Current Ratio pada tahun 2002 adalah sebesar 117,66\% yang berarti setiap Rp. 1,00 hutang lancar dijaminkan oleh Rp. 1,1766 aktiva lancar. Pada tahun 2003 Current Ratio mengalami peningkatan sebesar 156,80\% yang berarti setiap Rp. 1,00 hutang lancar dijaminkan oleh Rp. 1,5680 aktiva lancar. Dan pada tahun 2004 Current Ratio juga mengalami peningkatan sebesar $289,25 \%$ yang berarti setiap Rp. 1,00 hutang lancar dijaminkan oleh Rp. 2,8925 aktiva lancar. Nilai pada Current Ratio cenderung meningkat di tiap - tiap tahunnya. Namun nilai pada tahun 2002 dan 2003 apabila dibandingkan dengan rata-rata industri memiliki nilai rasio yang kurang baik karena dibawah 200\%, namun pada tahun 2004 dapat dikatakan sangat baik karena nilai rasio di atas rata-rata industri. Semakin besar rasio ini maka semakin besar kemampuan perusahaan untuk membayar kewajiban jangka pendeknya.

\section{- Dari Rasio Solvabilitas sebelum Merger}

\section{Debt to Total Assets Ratio}

Berdasarkan analisis Debt to Total Assets Ratio pada tahun 2002 adalah sebesar 67,68\% yang berarti setiap Rp. 1,00 aktiva didanai oleh hutang sebesar Rp. 0,6768. Pada tahun 2003 Debt to Total Assets Ratio mengalami penurunan sebesar 58,19\% yang berarti setiap Rp. 1,00 aktiva didanai oleh hutang sebesar Rp. 0,5819 dan pada tahun 2004 Debt to Total Assets Ratio juga mengalami penurunan sebesar 53,97\% yang berarti setiap Rp. 1,00 aktiva didanai oleh hutang sebesar Rp. 0,5397.

\section{- Dari Rasio Profitabilitas sesudah Merger :}

\section{Net Profit Margin}

Berdasarkan analisis Net Profit Margin pada PT. Kalbe Farma untuk tahun 2005 sebesar 10,66\% yang artinya bahwa setiap Rp. 1,00 penjualan akan menghasilkan laba bersih Rp. 0,1066. Pada tahun 2006 terjadi peningkatan yaitu sebesar $11,14 \%$, yang artinya bahwa setiap Rp. 100, penjualan akan menghasilkan laba bersih sebesar Rp. 0,1114. Pada tahun 2007 terjadi penurunan yaitu sebesar 10,07\%, yang artinya berarti bahwa setiap Rp.100, penjualan akan menghasilkan laba bersih sebesar Rp. 0,1007. Pada tahun 2008 terjadi penurunan yaitu sebesar 8,97\%, yang artinya berarti bahwa setiap Rp.100, penjualan akan menghasilkan laba bersih sebesar Rp. 0,0897. Pada tahun 2009 terjadi peningkatan yaitu sebesar 10,22\%, yang artinya bahwa setiap Rp. 100, penjualan akan menghasilkan laba bersih sebesar Rp. 0,1022. Pada tahun 2010 juga terjadi peningkatan yaitu sebesar 12,58\%, yang artinya bahwa setiap Rp. 100, penjualan akan menghasilkan laba bersih sebesar Rp. 0,1258. Pada tahun 2011 terjadi peningkatan yaitu sebesar $14,11 \%$, yang artinya bahwa setiap Rp. 100, penjualan akan menghasilkan laba bersih sebesar Rp. 0,1411. Namun pada tahun 2012 terjadi penurunan yaitu sebesar 12,99\%, yang artinya berarti bahwa setiap Rp.100, penjualan akan menghasilkan laba bersih sebesar Rp. 0,1299. Dan pada tahun 2013 juga terjadi penurunan yaitu sebesar 12,52\%, yang artinya berarti bahwa setiap Rp.100, penjualan akan menghasilkan laba bersih sebesar Rp. 0,1252.

\section{Return On Investment}


Berdasarkan analisis Return On Investment pada PT. Kalbe Farma untuk tahun 2005 sebesar 13,51\% yang artinya bahwa dalam setiap penjualan Rp. 1,00 total aktiva yang digunakan memberikan keuntungan Rp. 0,1351. Pada tahun 2006 terjadi peningkatan yaitu sebesar 14,63\%, yang artinya bahwa dalam setiap penjualan Rp. 1,00 total aktiva yang digunakan memberikan keuntungan Rp. 0,1463. Pada tahun 2007 terjadi penurunan yaitu sebesar 13,73\%, yang artinya bahwa dalam setiap penjualan Rp. 1,00 total aktiva yang digunakan memberikan keuntungan Rp. 0,1373. Pada tahun 2008 kembali terjadi penurunan yaitu sebesar 12,39\%, yang artinya bahwa dalam setiap penjualan Rp. 1,00 total aktiva yang digunakan memberikan keuntungan Rp. 0,1239. Pada tahun 2009 terjadi peningkatan yaitu sebesar 14,33\%, yang artinya bahwa dalam setiap penjualan Rp. 1,00 total aktiva yang digunakan memberikan keuntungan Rp. 0,1433. Pada tahun 2010 terjadi peningkatan yaitu sebesar 18,29\%, yang artinya bahwa dalam setiap penjualan Rp. 1,00 total aktiva yang digunakan memberikan keuntungan Rp. 0,1829. Pada tahun 2011 terjadi peningkatan yaitu sebesar $18,61 \%$, yang artinya bahwa dalam setiap penjualan Rp. 1,00 total aktiva yang digunakan memberikan keuntungan Rp. 0,1861. Pada tahun 2012 terjadi peningkatan yaitu sebesar $18,82 \%$, yang artinya bahwa dalam setiap penjualan Rp. 1,00 total aktiva yang digunakan memberikan keuntungan Rp. 0,1882. Dan pada tahun 2013 terjadi penurunan yaitu sebesar 17,71\%, yang artinya bahwa dalam setiap penjualan Rp. 1,00 total aktiva yang digunakan memberikan keuntungan Rp. 0,1771 .

\section{Return On Equity}

Berdasarkan analisis Return On Equity pada PT. Kalbe Farma untuk tahun 2005 sebesar 26,84\% yang artinya bahwa setiap Rp. 1,00 modal sendiri yang diinvestasikan akan menghasilkan laba bersih Rp. 0,2684. Pada tahun 2006 terjadi penurunan yaitu sebesar 22,59\%, yang artinya bahwa setiap Rp. 1,00 modal sendiri yang diinvestasikan menghasilkan laba bersih sebesar Rp. 0,2259. Pada tahun 2007 juga terjadi penurunan yaitu sebesar $20,84 \%$, yang artinya berarti bahwa setiap Rp.1,00 modal sendiri yang diinvestasikan menghasilkan laba bersih sebesar Rp. 0,2084. Pada tahun 2008 juga kembali terjadi penurunan yaitu sebesar 19,51\%, yang artinya berarti bahwa setiap Rp.1,00 modal sendiri yang diinvestasikan menghasilkan laba bersih sebesar Rp. 0,1951. Pada tahun 2009 terjadi peningkatan yaitu sebesar 21,55\%, yang artinya berarti bahwa setiap Rp.1,00 modal sendiri yang diinvestasikan menghasilkan laba bersih sebesar Rp. 0,2155. Pada tahun 2010 juga terjadi peningkatan yaitu sebesar 23,94\%, yang artinya berarti bahwa setiap Rp.1,00 modal sendiri yang diinvestasikan menghasilkan laba bersih sebesar Rp. 0,2394. Pada tahun 2011 terjadi penurunan yaitu sebesar 23,63\%, yang artinya berarti bahwa setiap Rp.1,00 modal sendiri yang diinvestasikan menghasilkan laba bersih sebesar Rp. 0,2363. Pada tahun 2012 terjadi peningkatan yaitu sebesar 24,04\%, yang artinya berarti bahwa setiap Rp.100 modal sendiri yang diinvestasikan menghasilkan laba bersih sebesar Rp. 0,2404. Dan pada tahun 2013 kembali terjadi penurunan yaitu sebesar $23,58 \%$, yang artinya berarti bahwa setiap Rp.100 modal sendiri yang diinvestasikan menghasilkan laba bersih sebesar Rp. 0,2358.

\section{- Dari Rasio Pasar sesudah Merger}

\section{Earning Per Share}

Rasio ini menggambarkan besarnya pengembalian modal untuk setiap satu lembar saham yang dimiliki. Dari hasil perhitungan Earning Per Share pada tahun 2005 sebesar 6164,99\% yang berarti untuk setiap satu lembar saham yang dimiliki akan menghasilkan laba sebesar 0,616499. Pada tahun 2006 terjadi peningkatan sebesar $6661,88 \%$ yang berarti untuk setiap satu lembar saham yang dimiliki akan menghasilkan laba sebesar 0,666188. pada tahun 2007 juga terjadi peningkatan sebesar 7067,36\% yang berarti untuk setiap satu lembar saham yang dimiliki akan menghasilkan laba sebesar 0,706736. pada tahun 2008 juga terjadi peningkatan sebesar $7378,70 \%$ yang berarti untuk setiap satu lembar saham yang dimiliki akan menghasilkan laba sebesar 0,737870. pada tahun 2009 terjadi peningkatan sebesar 9910,93\% yang berarti untuk setiap satu lembar saham yang dimiliki akan menghasilkan laba sebesar 0,991093. pada tahun 2010 juga terjadi peningkatan sebesar 13720,82\% yang berarti untuk setiap satu lembar saham yang dimiliki akan menghasilkan laba sebesar 0,1372082. pada tahun 2011 juga kembali terjadi peningkatan sebesar 16423,65\% yang berarti untuk setiap satu lembar saham yang dimiliki akan 
menghasilkan laba sebesar 1,642365.pada tahun 2012 terjadi penurunan sebesar 3489,63\% yang berarti untuk setiap satu lembar saham yang dimiliki akan menghasilkan laba sebesar 0,348963. Dan pada tahun 2013 terjadi peningkatan sebesar 4275,71\% yang berarti untuk setiap satu lembar saham yang dimiliki akan menghasilkan laba sebesar 0,427571. Dengan membandingkan nilai Earning Per Share bisa dilihat bahwa setiap tahunnya terjadi fluktuasi dimana pada tahun 2005 - 2011 mengalami peningkatan dan pada tahun 2012 - 2013 mengalami penururnan dibandingkan taun sebelumnya. Peningkatan dan penurunan disebabkan banyaknya saham beredar namun tidak di imbangi dengan naiknya laba yang segnifikan.

\section{Price Earning Rasio}

Berdasarkan analisis Price Earning Ratiopada tahun 2005 sebesar 19,46\%, yang berarti investor bersedia membayar Rp. 0,1946 untuk setiap Rp. 1,00 dari laba bersih yang dihasilkan perusahaan. pada tahun 2006 mengalami peningkatan sebesar 26,27\%, yang berarti investor bersedia membayar Rp. 0,2627 untuk setiap Rp. 1,00 dari laba bersih yang dihasilkan perusahaan.pada tahun 2007 mengalami penurunan sebesar 16,98\%, yang berarti investor bersedia membayar Rp. 0,1698 untuk setiap Rp. 1,00 dari laba bersih yang dihasilkan perusahaan. pada tahun 2008 mengalami penurunan sebesar 5,42\%, yang berarti investor bersedia membayar Rp. 0,0542 untuk setiap Rp. 1,00 dari laba bersih yang dihasilkan perusahaan. pada tahun 2009 mengalami peningkatan sebesar $13,11 \%$, yang berarti investor bersedia membayar Rp. 0,1311 untuk setiap Rp. 1,00 dari laba bersih yang dihasilkan perusahaan. pada tahun 2010 mengalami peningkatan sebesar 23,69\%, yang berarti investor bersedia membayar Rp. 0,2369 untuk setiap Rp. 1,00 dari laba bersih yang dihasilkan perusahaan. pada tahun 2011 mengalami penurunan sebesar 20,70\%, yang berarti investor bersedia membayar Rp. 0,2070 untuk setiap Rp. 1,00 dari laba bersih yang dihasilkan perusahaan. pada tahun 2012 mengalami peningkatan sebesar 30,09\%, yang berarti berarti investor bersedia membayar Rp. 0,3009 untuk setiap Rp. 1,00 dari laba bersih yang dihasilkan perusahaan. pada tahun 2013 mengalami penurunan sebesar 28,07\%, yang berarti berarti investor bersedia membayar Rp. 0,2807 untuk setiap Rp. 1,00 dari laba bersih yang dihasilkan perusahaan.

\section{Dari Rasio Aktivitas sesudah Merger}

\section{Total Asset Turn Over}

Berdasarkan analisis Total Asset Turn Over pada tahun 2005 sebesar 1,24 kali, yang artinya penjualan yang dihasilkan sebesar 1,24 kali dari total aktiva. Pada tahun 2006 Total Asset Turn Over mengalami peningkatan sebesar 1,31 kali yang artinya penjualan yang dihasilkan sebesar 1,31 kali dari total aktiva. pada tahun 2007 mengalami peningkatan yaitu sebesar 1,36 kali yang artinya penjualan yang dihasilkan sebesar 1,36 kali dari total aktiva. pada tahun 2008 mengalami peningkatan yaitu sebesar 1,38 kali yang artinya penjualan yang dihasilkan sebesar 1,38 kali dari total aktiva. pada tahun 2009 mengalami peningkatan yaitu sebesar 1,42 kali yang artinya penjualan yang dihasilkan sebesar 1,42 kali dari total aktiva. pada tahun 2010 mengalami peningkatan yaitu sebesar 1,45 kali yang artinya penjualan yang dihasilkan sebesar 1,45 kali dari total aktiva. pada tahun 2011 mengalami penurunan yaitu sebesar 1,32 kali yang artinya penjualan yang dihasilkan sebesar 1,32 kali dari total aktiva, pada tahun 2012 mengalami peningkatan yaitu sebesar 1, 45 kali yang artinya penjualan yang dihasilkan sebesar 1,45 kali dari total aktiva. Dan pada tahun 2013 mengalami penurunan yaitu sebesar 1,41 kali yang artinya penjualan yang dihasilkan sebesar 1,41 kali dari total aktiva.Nilai Total Asset Turn Over setiap tahun mengalami fluktuasi. Penurunan nilai Total Asset Turn Overdari tahun ke tahun ini menunjukkan bahwa kurangnya efisiensi penggunaan seluruh modal yang dimiliki dalam menghasilkan penjualan. Penurunan Total Asset Turn Overdari tahun ke tahun disebabkan karena adanya presentase kenaikan penjualan atau pendapatan jasa yang lebih kecil dibandingkan dengan presentase kenaikan aktiva.

\section{- Dari Rasio Likuiditas sesudah Merger}

\section{Current Ratio}

Berdasarkan analisis Current Ratio pada tahun 2005 adalah sebesar 331,59\% yang berarti setiap Rp. 1,00 hutang lancar dijaminkan oleh Rp. 3,3159 aktiva lancar. Pada tahun 2006 Current Ratio mengalami penurunan sebesar 354,83\% yang berarti setiap Rp. 1,00 hutang lancar dijaminkan oleh Rp. 3,5483 aktiva lancar. pada tahun 2007 Current Ratio mengalami peningkatan sebesar 498,26\% yang berarti setiap Rp. 1,00 hutang lancar dijaminkan oleh Rp. 4,9826 aktiva lancar. Pada tahun 2008 Current Ratio mengalami 
penurunan sebesar 333,35\% yang berarti setiap Rp. 1,00 hutang lancar dijaminkan oleh Rp. 3,3335 aktiva lancar. Pada tahun 2009 Current Ratio juga mengalami penurunan sebesar 298,69\% yang berarti setiap Rp. 1,00 hutang lancar dijaminkan oleh Rp. 2,9869 aktiva lancar. pada tahun 2010 Current Ratio mengalami peningkatan sebesar 439,36\% yang berarti setiap Rp. 1,00 hutang lancar dijaminkan oleh Rp. 4,3936 aktiva lancar. Pada tahun 2011 Current Ratio mengalami penurunan sebesar 367,59\% yang berarti setiap Rp. 1,00 hutang lancar dijaminkan oleh Rp. 3,6759 aktiva lancar. Pada tahun 2012 Current Ratio juga mengalami penurunan sebesar 340,54\% yang berarti setiap Rp. 1,00 hutang lancar dijaminkan oleh Rp. 3,4054 aktiva lancar. Pada tahun 2013 Current Ratio juga kembali mengalami penurunan sebesar 283,93\% yang berarti setiap Rp. 1,00 hutang lancar dijaminkan oleh Rp. 2,8392 aktiva lancar. Nilai pada Current Ratio cenderung berfluktuatif di tiap - tiap tahunnya. Namun apabila dibandingkan dengan ratarata industri memiliki nilai rasio yang sangat baik karena dibawah 200\%. Semakin besar rasio ini maka semakin besar kemampuan perusahaan untuk membayar kewajiban jangka pendeknya.

\section{- Dari Rasio Solvabilitas sesudah Merger}

\section{Debt to Total Assets Ratio}

Berdasarkan analisis Debt to Total Assets Ratio pada tahun 2005 adalah sebesar 39,31\% yang berarti setiap Rp. 1,00 aktiva didanai oleh hutang sebesar Rp. 0,3931. Pada tahun 2006 Debt to Total Assets Ratio mengalami penurunan sebesar 23,36\% yang berarti setiap Rp. 1,00 aktiva didanai oleh hutang sebesar Rp. 0,5819. Pada tahun 2007 Debt to Total Assets Ratio juga mengalami penurunan sebesar 21,82\% yang berarti setiap Rp. 1,00 aktiva didanai oleh hutang sebesar Rp. 0,2182. Pada tahun 2008 Debt to Total Assets Ratio mengalami peningkatan sebesar 23,83\% yang berarti setiap Rp. 1,00 aktiva didanai oleh hutang sebesar Rp. 0,2383. Pada tahun 2009 Debt to Total Assets Ratio juga mengalami peingkatan sebesar 26,09\% yang berarti setiap Rp. 1,00 aktiva didanai oleh hutang sebesar Rp. 0,2609. Pada tahun 2010 Debt to Total Assets Ratio mengalami penurunan sebesar 17,92\% yang berarti setiap Rp. 1,00 aktiva didanai oleh hutang sebesar Rp. 0,1792. Pada tahun 2011 Debt to Total Assets Ratio mengalami peningkatan sebesar 21,25\% yang berarti setiap Rp. 1,00 aktiva didanai oleh hutang sebesar Rp. 0,2125. Pada tahun 2012 Debt to Total Assets Ratio juga mengalami peingkatan sebesar 21,73\% yang berarti setiap Rp. 1,00 aktiva didanai oleh hutang sebesar Rp. 0,2173. Pada tahun 2013 Debt to Total Assets Ratio kembali mengalami peningkatan sebesar 33,12\% yang berarti setiap Rp. 1,00 aktiva didanai oleh hutang sebesar Rp. 0,3312.

\subsection{Kesimpulan}

\section{KESIMPULAN DAN SARAN}

Berdasarkan hasil penelitian, maka dapat ditarik kesimpulan sebagai berikut :

1. Kinerja keuangan PT. Kalbe Farma ditinjau dari rasio profitabilitas terjadi fluktuasi, artinya rasio ini mengalami naik turun setiap tahunnya. Namun dilihat dari Net Profit Margin sebelum merger pada tahun 2002 sebesar 10,42\%, tahun 2003 sebesar 11,18\%, tahun 2004 sebesar 10,91\% dan sesudah merger pada tahun 2005 sebesar 10.66\%, tahun 2006 sebesar 11,14\%, tahun 2007 sebesar 10,07\%, tahun 2008 sebesar $8,97 \%$, tahun 2009 sebesar 10,22\%, tahun 2010 sebesar 12,58\%, pada tahun 2011 sebesar 14,11\%, pada tahun 2012 sebesar 12,99\%, tahun 2013 sebesar 12,52\%. Dilihat dari Return On Investmentsebelum merger pada tahun 2002 sebesar 13,24\%, tahun 2003 sebesar 13,19\%, tahun 2004 sebesar 12,34\% dan sesudah merger pada tahun 2005 sebesar 13,51\%, tahun 2006 sebesar 14,63\%, tahun 2007 sebesar $13,73 \%$, tahun 2008 sebesar 12,39\%, tahun 2009 sebesar 14,33\%, tahun 2010 sebesar 18,29\%, pada tahun 2011 sebesar 18,61\%, pada tahun 2012 sebesar 18,82\%, tahun 2013 sebesar 17,71\%. Dan dilihat dari Return On Equitysebelum merger pada tahun 2002 sebesar 54,49\%, tahun 2003 sebesar 38,95\%, tahun 2004 sebesar 30,54\%dan sesudah merger pada tahun 2005 sebesar 26,84\%, tahun 2006 sebesar 22,59\%, tahun 2007 sebesar 20,84\%, tahun 2008 sebesar 19,51\%, tahun 2009 sebesar 21,55\%, tahun 2010 sebesar 23,94\%, pada tahun 2011 sebesar 23,63\%, pada tahun 2012 sebesar 24,04\%, tahun 2013 sebesar 23,58\%.

Diukur dari rasio profitabilitas didapati bahwa kinerja keuangan PT. Kalbe Farma mengalami fluktuasi, Namun kemampuan perusahaan dalam menghasilkan laba kurang baik karena berada dibawah standar industri tetapi perusahaan masih mampu menurunkan biaya dan meningkatkan pendapatan serta mampu mengelola modal yang diinvestasikan dalam seluruh aktiva untuk menghasilkan laba. Peningkatan ini 
disebabkan oleh kemampuan menggunakan modal sendiri dengan baik sehingga mengalami peningkatan laba yang dihasilkan perusahaan.

2. Kinerja keuangan PT. Kalbe Farma jika dilihat dengan menggunakan rasio pasar yang diukur dengan Earning Per Sharesebelum merger pada tahun 2002 sebesar 65,73\% tahun 2003 sebesar 39,76\%, tahun 2004 sebesar 45,85\%dan sesudah merger pada tahun 2005 sebesar 61,65\%, tahun 2006 sebesar 66,62\%, tahun 2007 sebesar 70,67\%, tahun 2008 sebesar 73,79\%, tahun 2009 sebesar 99,11\%, tahun 2010 sebesar 137,21\%, pada tahun 2011 sebesar 164,24\%, pada tahun 2012 sebesar 37,80\%, dan tahun 2013 sebesar 42,76\%. Dan dilihat dari Price Earning Ratio sebelum merger pada tahun 2002 sebesar 4,56\% tahun 2003 sebesar $25,15 \%$, tahun 2004 sebesar 10,81\%dan sesudah merger pada tahun 2005 sebesar 19,46\%, tahun 2006 sebesar 26,27\%, tahun 2007 sebesar 16,98\%, tahun 2008 sebesar 5,42\%, tahun 2009 sebesar 13,11\%, tahun 2010 sebesar 23,69\%, pada tahun 2011 sebesar 20,70\%, pada tahun 2012 sebesar 30,09\%, dan tahun 2013 sebesar 28,07\%.

3. Kinerja keuangan PT. Kalbe Farma jika dilihat dengan menggunakan rasio aktivitas yang diukur dengan Total Assets Turn Oversebelum merger pada tahun 2002 sebesar 1,27 kali, tahun 2003 sebesar 1,18 kali, tahun 2004 sebesar 1,19 kali dan sesudah merger pada tahun 2005 sebesar 1,24 kali, tahun 2006 sebesar 1,31 kali, tahun 2007 sebesar 1,36 kali, tahun 2008 sebesar 1,38 kali, tahun 2009 sebesar1,40 kali, tahun 2010 sebesar 1,45 kali, pada tahun 2011 sebesar 1,32 kali, pada tahun 2012 sebesar 1,45 kali, dan tahun 2013 sebesar 1,41 kali.

Kinerja keuangan PT. Kalbe Farma dilihat Total Asset Turn Over dapat dikatakan kurang baik karena berada dibawah rata- rata industri sebesar 1,8 kali. semakin rendah rasio Total Asset Turn Over berarti tidak menunjukan efisiensi penggunaan keseluruhan aktiva di dalam menghasilkan tingkat penjualan yang tinggi.

4. Kinerja keuangan PT. Kalbe Farma jika dilihat dengan menggunakan rasio likuiditas yang diukur dengan Current Ratio sebelum merger pada tahun 2002 sebesar 117,66\%, tahun 2003 sebesar 156,80\%, tahun 2004 sebesar 300,98\% dan sesudah merger pada tahun 2005 sebesar 331,59\%, tahun 2006 sebesar $254,83 \%$, tahun 2007 sebesar 498,26\%, tahun 2008 sebesar 333,35\%, tahun 2009 sebesar298,69\%, tahun 2010 sebesar 439,36\%, pada tahun 2011 sebesar 367,59\%, pada tahun 2012 sebesar 340,54\%, dan tahun 2013 sebesar $283,93 \%$.

Diukur dari current rasio didapati kinerja keuangan PT. Kalbe Farma sesudah merger mengalami peningkatan yang lebih baik dari sebelum merger. dapat dilihat dari hasil analisis pada tahun 2005 - 2013 nilai berada di atas rata - rata industri. Hal ini dapat dikatakan bahwa PT. Kalbe Farma sangat mampu dalam menjamin hutang - hutangnya yang akan segera jatuh tempo menggunakan aktiva yang dimilikinya.

5. Kinerja keuangan PT. Kalbe Farma jika dilihat dengan menggunakan rasio solvabilitas yang diukur dengan Debt to Total Assets Ratiosebelum merger pada tahun 2002 sebesar 67,68\%, tahun 2003 sebesar 58,19\%, tahun 2004 sebesar 50,96\%dan sesudah merger pada tahun 2005 sebesar 39,31\%, tahun 2006 sebesar 23,36\%, tahun 2007 sebesar 21,82\%, tahun 2008 sebesar 23,83\%, tahun 2009 sebesar26,09\%, tahun 2010 sebesar 17,92\%, pada tahun 2011 sebesar 21,25\%, pada tahun 2012 sebesar 21,73\%, dan tahun 2013 sebesar 33,12\%.

Diukur dari rasio solvabilitas didapati kinerja keuangan PT. Kalbe Farma sesudah merger mengalami peningkatan yang lebih baik dari sebelum merger. dapat dilihat dari hasil analisis pada tahun 2005 - 2013 nilai berada dibawah rata - rata industri. Hal ini dapat dikatakan bahwa PT. Kalbe Farma hanya memiliki sedikit aktiva yang dibiayai oleh hutang.

\section{Saran}

1. Meningkatkan kinerja perusahaan dengan meningkatkan kualitas sumber daya manusia agar perusahaan dapat lebih baik lagi.

2. PT. Kalbe Farma memiliki rasio profitabilitas yang kurang baik, untuk meningkatkan laba di tahun berikutnya perusahaan harusmampu mengelola modal yang diinvestasikan dalam aktiva danmeningkatkan pendapatan bersih untuk memperoleh laba bersih yanglebih baik.

3. Menciptakan Produk - produk baru yang lebih inovatif dan berdaya saing tinggi. 


\section{DAFTAR PUSTAKA}

Djumingan. 2006. Analisa Laporan Keuangan, Penerbit Bumi Aksara. Jakarta,

Gitosudarmo, Indriyodan Basri. 2002. Manajemen Keuangan, BPFF. Yogyakarta

Horne, James C. Van dan John M. Wachowicz. Jr. 2003. Fundamentals of Financial Management.New Jersey, Prentice Hall Inc.

Irawati, Susan. 2006. Manajemen Keuangan,Pustaka. Bandung

Moin, Abdul. 2010.Merger, Akuisisi, \& Divestasi, Edisi Kedua, Cetakan ke tiga. Penerbit EKONISIA. Kampus Fakultas Ekonomi UII. Yogyakarta.

Riyanto, Bambang. 2001. Dasar - dasar Pembelanjaan Perusahaan, Edisi keempat, Cetakan ketiga, BPFE Universitas Gajah Mada. Yogyakarta.

Sartono, Agus. 2001. Manajemen Keuangan : Teori dan Aplikasi.BPFE Universitas Gajah Mada.Yogyakarta.

Setia Atmaja, Lukas. 2008. Teori \& Praktik Manajemen Keuangan. Penerbit ANDI. Yogyakarta.

Syamsuddin, Lukman. 2002. Manajemen Keuangan Perusahaan, Edisi Baru,Cetakan ke tujuh. Penerbit Rajawali Pers. Jakarta.

Weston, Fred dan Eugene F. Brigham, 2000.Manajemen Keuangan, Jilid 1 Edisi kesembilan, Penerbit Erlangga. Jakarta.

Merger dan Akuisisi : Pengertian, Jenis, Alasan, Kelebihan Dan Kekurangan Merger dan Akuisisi.

http://jurnal-sdm.blogspot.co.id/2009/07/merger-dan-akuisisi-pengertian-jenis, diakses hari Rabu 15 Juli 2015.

Laporan Tahunan PT. Kalbe Farma, tbk, http://www.kalbe.co.id>investors. Diakses hari Senin 20 Juli 2015

Laporan Tahunan PT. Enseval, tbk, http://www.enseval.com>hubungan-investor. Diakses pada hari Senin 3 Agustus 2015

Laporan Tahunan PT. Dankos Laboratories, tbk, http://www.geocities.ws diakses pada hari Senin 3 agustus 2015 